\title{
Turbine Design for Low Heat Organic Rankine Cycle Power Generation using Renewable Energy Sources
}

\author{
Herry Susanto ${ }^{1}$, Kamaruddin Abdullah ${ }^{1, *}$, Aep Saepul Uyun ${ }^{1}$, Syukri Muhammad Nur ${ }^{1}$, and Teuku Meurah Indra Mahlia ${ }^{2,3}$ \\ ${ }^{1}$ Program Study of Renewable Energy, Graduate School, Darma Persada University, Jl. Radin Inten II, Pondok Kelapa 13450, \\ East Jakarta, Indonesia \\ ${ }^{2}$ Department of Mechanical Engineering, Universiti Tenaga Nasional, 43000 Kajang, Selangor, Malaysia \\ ${ }^{3}$ School of Systems, Management and Leadership, Faculty of Engineering and Information Technology, University of Technology \\ Sydney, 81 Broadway, Ultimo, NSW 2007, Australia
}

\begin{abstract}
In recent years, due to its feasibility and reliability, the organic rankine cycle has become a widespread concern and is the subject of research. In the organic rankine cycle system, the radial turbine component is a highly influential component of the high low performance resulting. This paper discusses the design of radial turbines for organic rankine cycle systems. The design stage consists of preliminary design and detail design with parametric methods on the working fluid R22 to determine the geometry and initial estimation of the performance of the radial turbine. After that, a numerical study of the fluid flow region in the radial turbine with R22 as the working fluid was performed. The analysis was performed using computational fluid dynamics of Autodesk Computational Fluid Dynamics Motion software on two models of real gas, k-epsilon and shear stress transport. From the results of this analysis, there is pressure, velocity and temperature distribution along the radial turbine blades and estimated performance under various operating conditions. Comparison between parametric and computational fluid dynamics analysis results show different performance. The difference is due to the computational fluid dynamics analysis already involving the real gas shear stress transport model.
\end{abstract}

Key words: Computational fluid dynamics, finite element analysis, k-epsilon, organic rankine cycle, shear stress transport.

\section{Introduction}

Interest in the utilization of low grade heat recovery has increased dramatically in the past decade as it increases environmental issues such as air pollution, global warming, ozone layer depletion and acid rain caused by the acceleration of fossil fuel consumption [1-3]. A number of new solutions have been proposed to produce heat-generated plants at low temperature and pressure, and has been proven to be applied in various fields such as solar thermal power, biological waste heat, engine exhaust gases, domestic boilers and so forth [3-11]. Among the solutions offered, for now the Organic Rankine Cycle (ORC) system is the most widely studied. ORC has at least two advantages, namely as a power generation system, ORC has simple components and the availability of components that are quite a lot in the market. Furthermore, ORC also uses organic working fluids that perform better than water as a working fluid at low temperature and pressure [12-18]. Various ORC applications have been reported in previous studies. As in the utilization of waste heat recovery, solar energy, a combination of heat and power (CHP), geothermal and heat utilization of the exhaust from the engine. From the results of the experimental study it is seen that on small scale units of ORC showed promising performance, especially in remote areas, because ORC has reliability, wide output power range, wide component parts availability and reduced number of rotating components so that the ORC construction can be more compact and smaller than that of conventional power plants. Many researchers have focused on the thermodynamic studies of the ORC cycle, and the selection of working fluids, with particular attention to the efficiency of power generation. On the other hand, relatively little writing is published on the design and optimization of turbomachinery

*Corresponding author: kamaruddinabd@gmail.com, smt.eng77@gmail.com 
equipment. Basically, within the relevant power range ( $5 \mathrm{~kW}$ to $5000 \mathrm{~kW})$ two options can be proposed: that is, axial turbine or radial turbine. This last option is considered more attractive, as it allows better performance on a lower scale. Therefore knowledge of radial turbines on ORC systems requires further study [19-29].

Organic Rankine Cycle (ORC) cycle is one form of Rankine cycle that utilizes organic refrigerant as a working fluid. In general, the ideal ORC has four process stages: isentropic compression at the pump, isobaric evaporation of the boiler, isentropic expansion on the turbine, and isobaric condensation on the condenser. The advantage of this cycle is to use a refrigerant with boiling point and condensation point lower than the water used in the regular Rankine cycle. The impact of using the refrigerant is that the cycle can utilize a heat source whose temperature is lower than the boiling temperature of water. Here is the entalpy-entropy diagram and temperature on ORC [12]. Simple Organic Rankine Cycle (ORC) and the Organic Rankine Cycle P-h diagram shown in Figure 1.
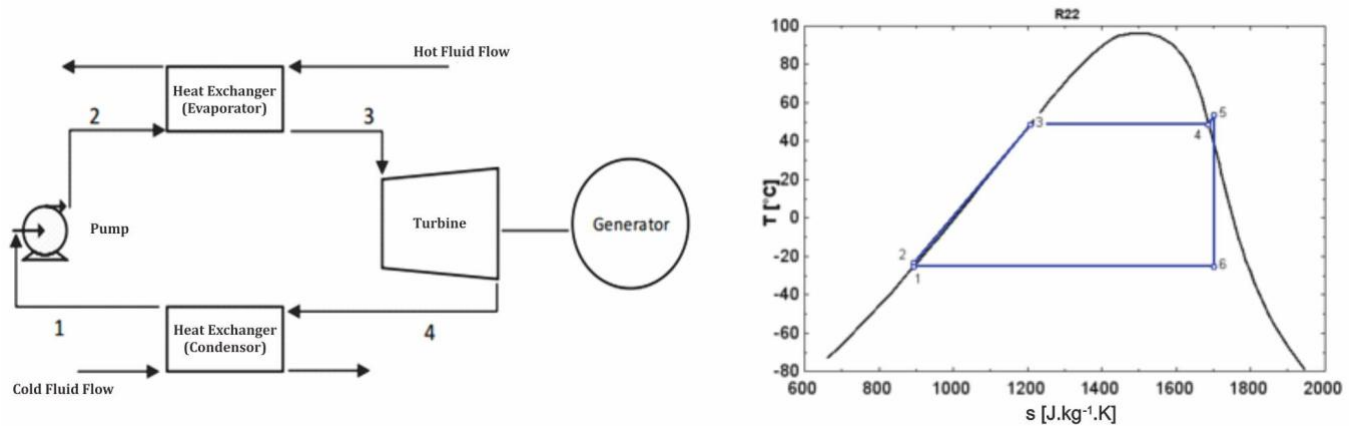

Fig. 1. Simple Organic Rankine Cycle (ORC) (left) and The Organic Rankine Cycle P-h diagram (right).

Working fluids have an important role in ORC as working conditions vary. There are also many number of compounds that can be used as a choice of working fluids including hydrocarbons refrigerants, alcohols and others [12]. Working fluids can be categorized into three types: dry, wet and isentropic fluid. The fundamental difference between the three types of refrigerant is the $\mathrm{dT} \mathrm{ds}^{-1}$ slope of the fluid vapor curve in the temperature-entropy diagram. Dry fluid has a positive $\mathrm{dT} \mathrm{ds}^{-1}$ slope, wet fluid has a negative $\mathrm{dT} \mathrm{ds}^{-1}$ slope, and isentropic fluid categorized if $\mathrm{dT} \mathrm{ds}^{-1}$ has a zero value [12]. As shown in Figure 2, there are generally three types of saturated steam curves in the T-s (Temperatureentropy) diagram. Dry fluid with positive slope, wet fluid with negative slope, and isentropic fluid.

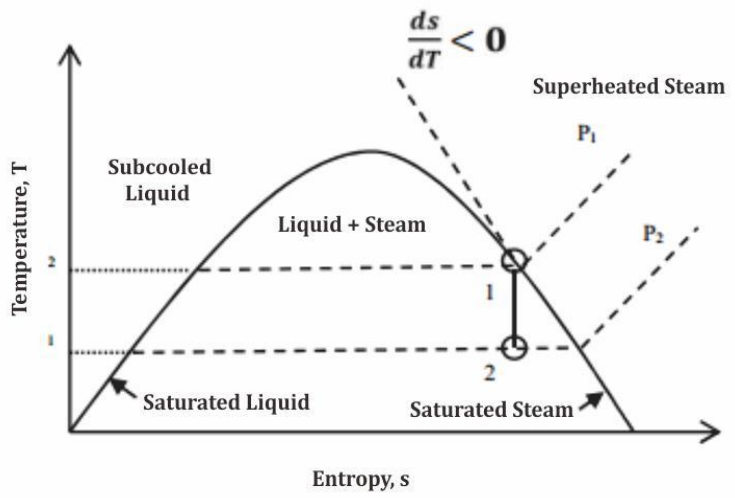

(a) 


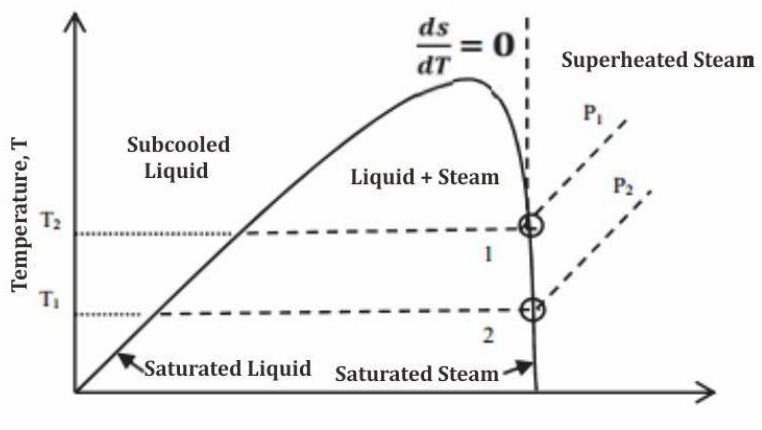

Entropy, $s$

\section{(b)}

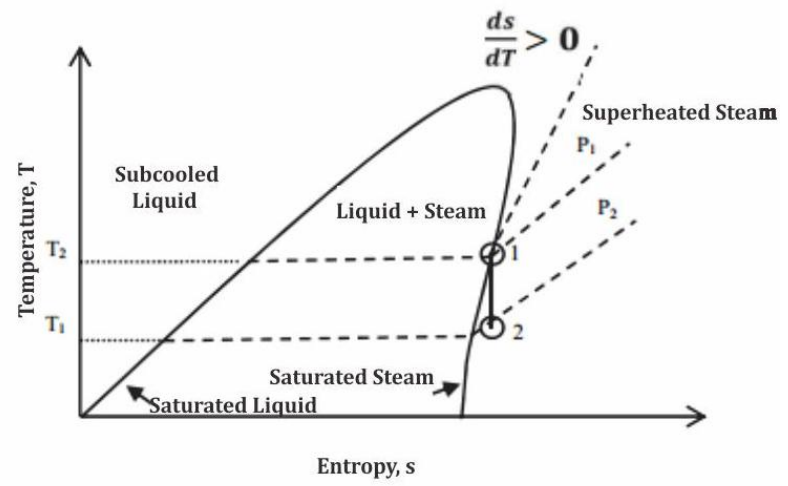

(c)

Fig. 2. T-s diagram for fluid (a) wet, (b) isentropic, and (c) dry.

The choice of working fluid should pay attention to the heat source to be used, the optimum criteria of thermodynamic properties, and meet various criteria such as non-toxic, non-flammable, and environmentally friendly. Currently, a system of power plants is being developed using renewable energy. The power plant system used is a power plant system using ORC (Organic Rankine Cycle) technology. This system generates electricity from renewable energy sources by utilizing low-temperature and low-pressure heat sources [21]. The advantage of using the ORC power plant system is simpler than through biomass gasification processes plus gas/diesel fuel engines when fueled by biomass. The cost required is about five times less than the utilization of other renewable energy. In addition, efficiency rises about three times as large as over-wasted capture [21]. Figure 3, shows the following components in an ORC (Organic Rankine Cycle) power plant: 


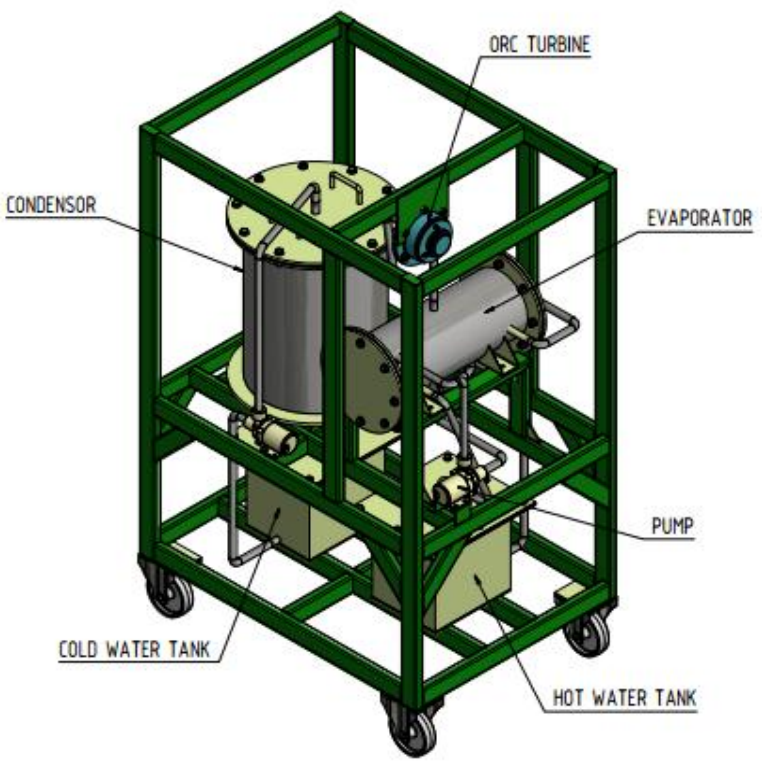

Fig. 3. ORC (Organic Rankine Cycle) power plant.

The above-mentioned ORC power plant can be developed as a substitute for generators in rural areas or areas where electricity supply is not available. In addition, the design of the ORC power plant can also be applied to power generation from other renewable energy sources, such as ocean thermal energy (OTEC), solar thermal, biological waste heat, engine exhaust gas, geothermal, biomass and other sources. By utilizing exhaust heat that is still hot and below $100{ }^{\circ} \mathrm{C}$ (range $65^{\circ} \mathrm{C}$ to $80^{\circ} \mathrm{C}$ ), it is connected to an ORC generator engine evaporator, and by heat transfer process will evaporate the organic working fluid inside the evaporator and increase the pressure inside the evaporator chamber. Furthermore, the flow of the working fluid will flow into the turbine that will turn the turbine runner as well as rotate the generator so that it can generate electricity.

In this turbine chamber begin to decrease the pressure of organic working fluid. Furthermore, the organic working fluid will flow into the condenser and there will be again the process of heat transfer so that the remaining heat in the working fluid will be absorbed by cold water taken from the cooling tower or other cold water source. As the organic working fluid is in the condenser and cools down, the working fluid pressure will be at the lowest point in the system requiring the pumping aid to suck up the organic working fluid and flush it back into the evaporator to continue the working cycle. Utilization of ORC power plant in renewable energy sources is shown in Figure 4 below:

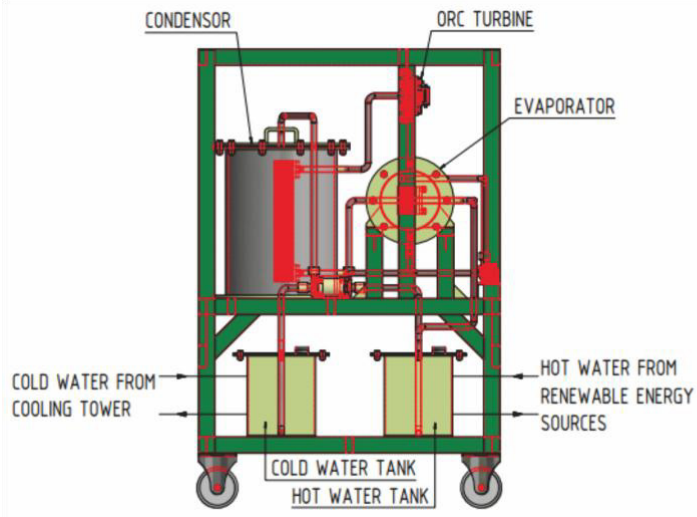

(a)

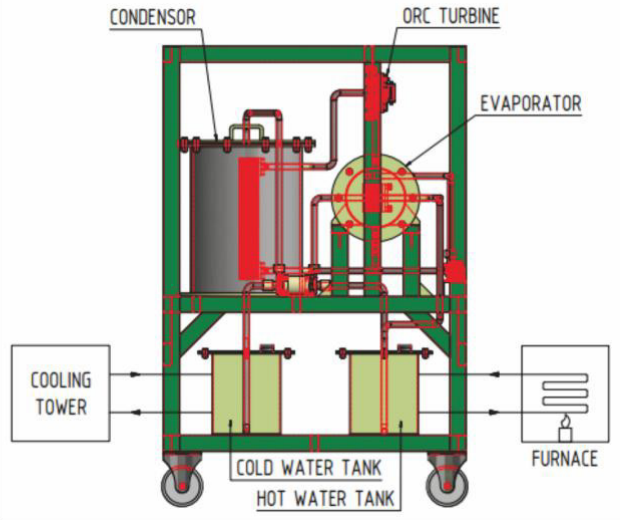

(b)

Fig. 4. Utilization of ORC (Organic Rankine Cycle) power plant (a) for renewable energy sources and (b) as replacement generator. 


\section{Research methodology}

\subsection{Research flow diagram}

In this paper, the research steps are shown in the following Research Flow Diagram in Figure 5 below:

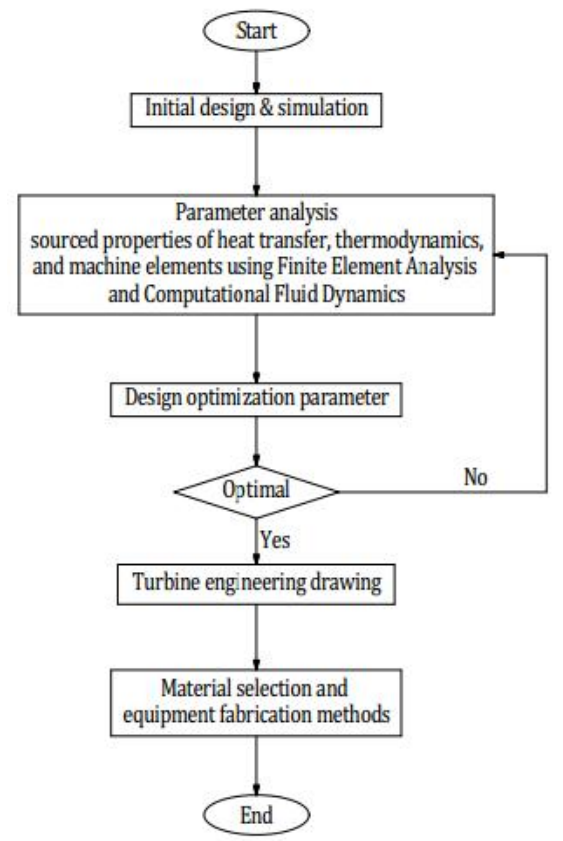

Fig. 5. Research flow diagram.

\subsection{ORC (Organic Rankine Cycle) turbine design}

The ORC turbine design to be studied can be seen in Figure 6, below:
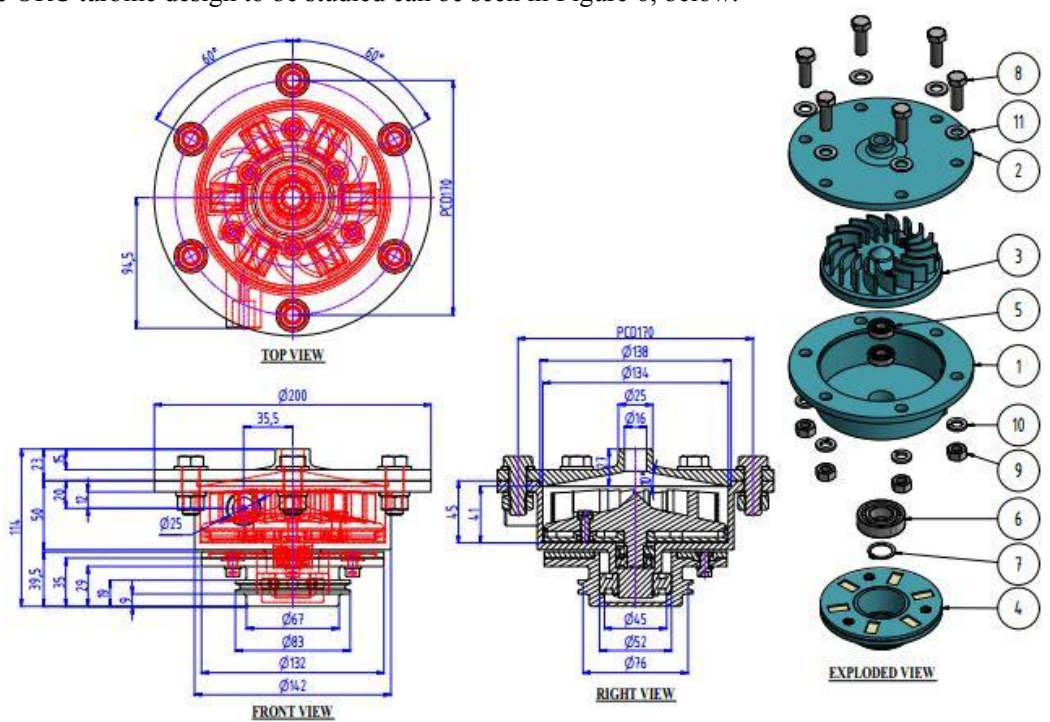

Fig. 6. ORC turbine components. 
The explanations of these components are as follows:

(i). Housing, is a major component of the ORC turbine, which houses the turbine runner and generator runner components as well as an inlet hole. In this paper research, housing component is designed using SUS 304 material. Selection of the material to optimize the use of magnets mounted on the turbine runner and generator runner, so it will not interfere with the magnetic pull force that occurs on both components. The housing component is shown in Figure 7, below:
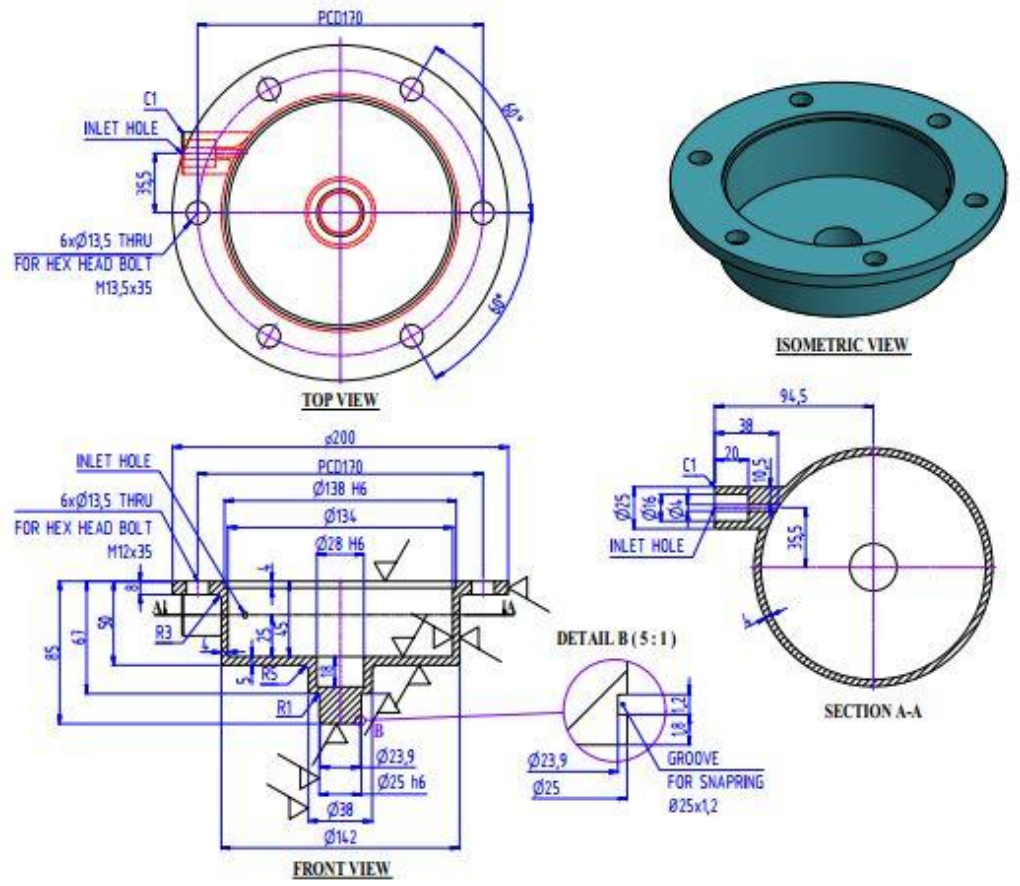

ISOMETRIC VIEW

Fig. 7. Housing component on ORC turbine.

(ii). Housing cover, is a major component of the ORC turbine which is the closing component of housing. In the housing cover component there is an outlet hole and the design is also made using SUS 304 material. The housing cover component is shown in Figure 8, below:
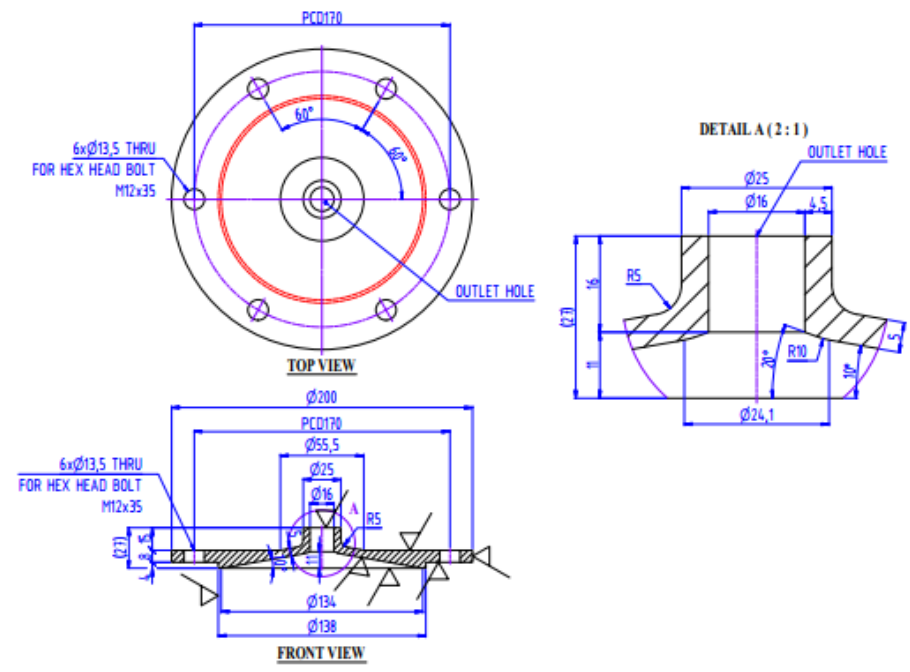

Fig. 8. Housing cover component on ORC turbine. 
(iii). Turbine runner, is a component of ORC turbine residing in the housing component. This component will rotate when receiving fluid pressure into the housing chamber. The greater the fluid pressure that goes in, the rotation on the turbine runner will also accelerate. While the magnet attached to the turbine runner will draw the magnet attached to the generator runner, so that when the turbine runner rotates due to the inlet working fluid pressure, it will cause the generator runner to rotates also in the direction of the turbine runner. The turbine runner component is shown in Figure 9, below:

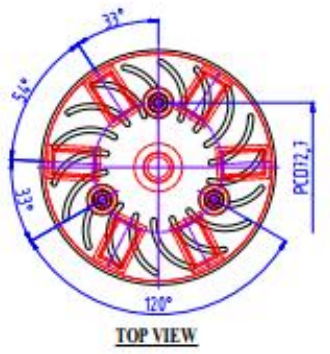

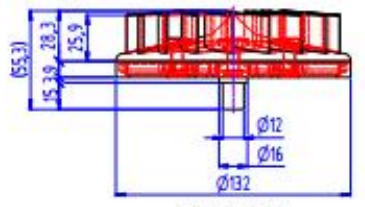

ERONT VIEW

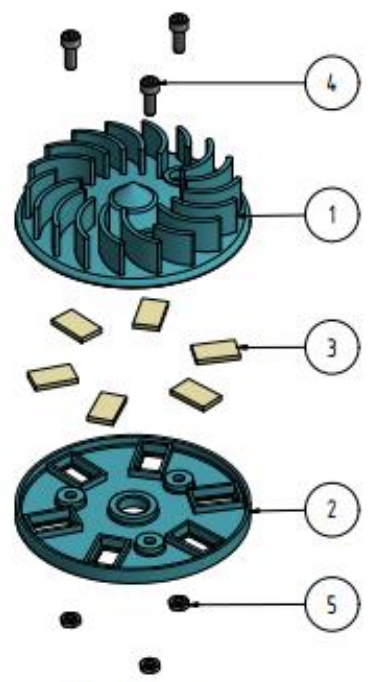

EXPLODED VIEW

Fig. 9. Turbine runner component on ORC turbine.

(iv). Generator runner, is a component of the ORC turbine that is outside the housing component. This component will rotate along with turbine runner's spin, because the magnets attached to the two components will attract each other. Furthermore, the generator runner component will be connected to the generator using the $\mathrm{V}$-Belt component, so that from the rotation that occurs in the generator will be converted into electrical energy. The generator runner component is shown in Figure 10, below:

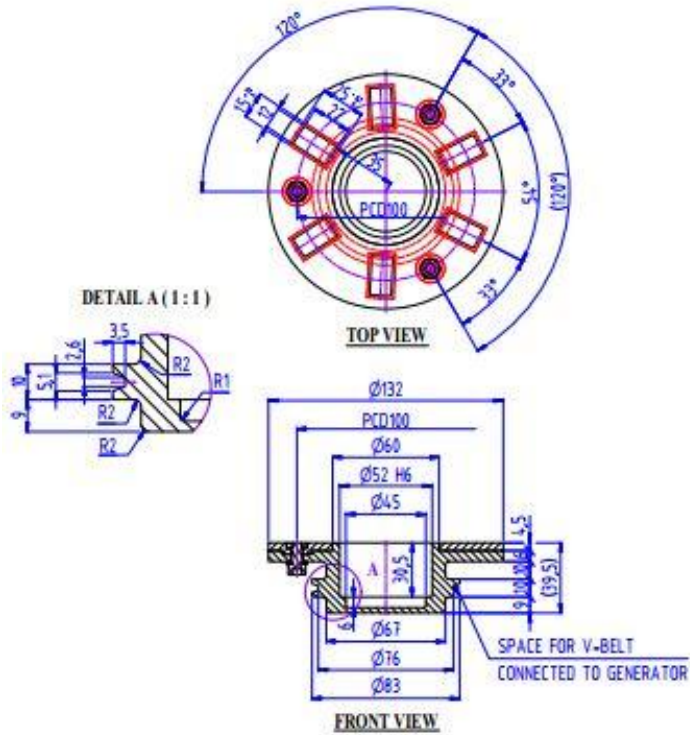

Fig. 10. Generator runner component on ORC turbine.

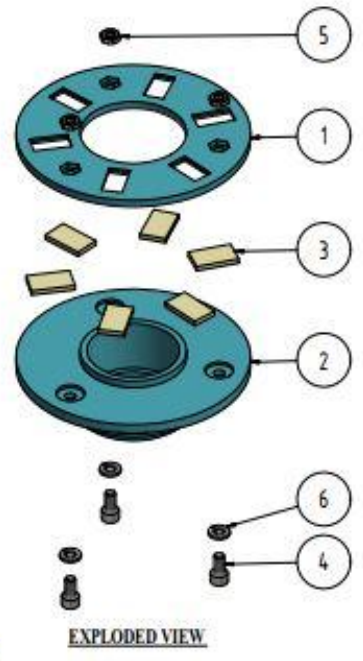

EXPLODED VIEW 


\subsection{Research stages}

The research activity is planned to be divided into two stages as follows:

i). The initial stage is the initial design of ORC turbine.

ii). ORC turbine movement simulation, fluid distribution inside the ORC turbine chamber, analysis of design parameters and analytical optimization.

\section{Mathematical modeling}

ORC (Organic Rankine Cycle) turbine has two main components groups which become the most important part of turbine system performance optimization, that is :

(i). Housing \& housing cover, both of these components are the main components to which the turbine runner and generator runner components are installed. Both of these components must also be able to withstand internal pressure that occurs due to the working fluid that flowed into the turbine chamber. The first step that we must do to make the design housing and housing cover is to determine its dimensions. Since housing and housing cover must be able to withstand internal pressure, it must be designed following the pressure vessel rules according to ASME Section VIII Division 1 standard.

(ii). Turbine runner, this component is a component that will rotate due to the pressure effect of the working fluid being fed into the turbine chamber. Therefore, this turbine runner needs to be designed by taking into account the pressure, velocity, temperature and density of the working fluid used. Although on this turbine runner installed magnets which will pull each other with magnets attached to the generator runner, but we will not analyze specifically the magnetic flux that occurs in the magnets attached to the turbine runner and generator runner. Design modeling and velocity triangle of turbine runner can be seen in Figure 11, below:

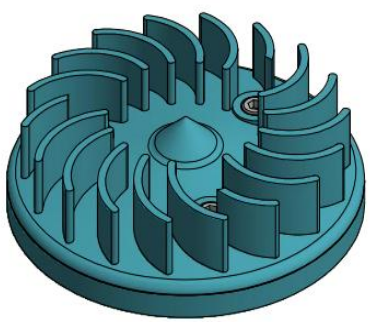

TOP ISOMETRIC VIEW

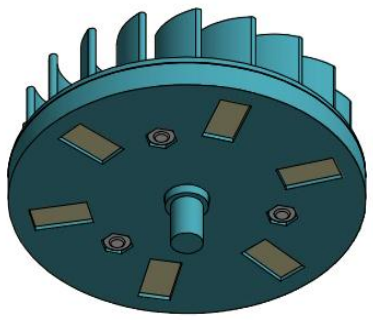

BOTTOM ISOMETRIC VIEW

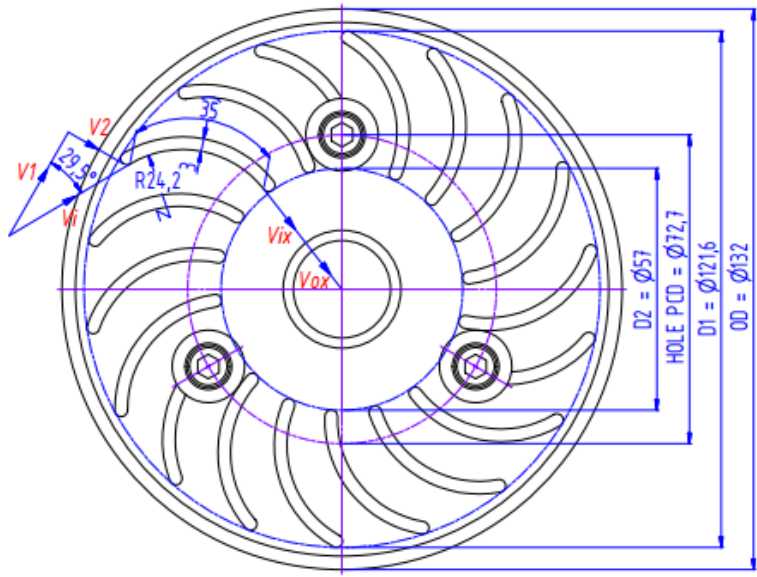

FRONT VIEW

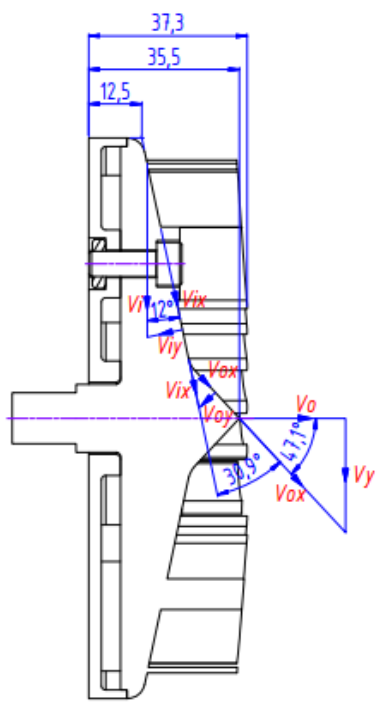

SIDE VIEW

Fig. 11. Modeling and velocity triangle of turbine runner. 
Mathematical modeling to calculate the amount of power generated, seen in the following Equation:

i). Turbine power $\left(\mathrm{P}_{\mathrm{T}}\right)$

The turbine power $\left(\mathrm{P}_{\mathrm{T}}\right)$, can be calculated using the following Equation [21]:

$$
P_{T}=\frac{T 2 \pi n}{60}
$$

ii). Electrical power $\left(\mathrm{P}_{\mathrm{L}}\right)$

The electrical power $\left(\mathrm{P}_{\mathrm{L}}\right)$, can be calculated using the following Equation [21]:

$$
P_{L}=P_{T} \eta_{g}
$$

Where : $\quad \mathrm{P}_{\mathrm{L}}=$ Electrical power $(\mathrm{W})$

$\mathrm{P}_{\mathrm{T}}=$ Turbine power $(\mathrm{W})$

$\mathrm{T}=$ Turbine torque $(\mathrm{N} \mathrm{m})$

$\mathrm{n}=$ Turbine rotation $(\mathrm{rpm})$

$\eta_{\mathrm{g}}=$ Generator efficiency $=82 \%=0.82$

\section{Turbine modeling and simulation}

\subsection{Turbine Design Parameters}

Table 1. Initial design parameter of housing and housing cover.

\begin{tabular}{cccc}
\hline No & Input Parameters & Value & Unit \\
\hline 1 & Material & SUS 304 & \\
\hline 2 & Design Pressure (P) & 0.8 & $\mathrm{MPa}$ \\
\hline 3 & Design Temperature (T) & 80 & ${ }^{\circ} \mathrm{C}$ \\
\hline 4 & Material Strength Value (S) & 215 & $\mathrm{MPa}$ \\
\hline 5 & Joint Efficiency (E) & 1 & \\
\hline 6 & Shell Inner Diameter (Ds) & 134 & $\mathrm{~mm}$ \\
\hline 7 & Inlet Nozzle Inner Diameter (Di) & 4 & $\mathrm{~mm}$ \\
\hline 8 & Outlet Nozzle Inner Diameter (Do) & 16 & $\mathrm{~mm}$ \\
\hline 9 & Corrosion Allowance (C.A.) & 1 & $\mathrm{~mm}$ \\
\hline
\end{tabular}

\begin{tabular}{|c|c|c|c|}
\hline No & Input Parameters & Value & Unit \\
\hline 1 & Material & PLASTIC & \\
\hline 2 & Design Pressure $(\mathrm{P})$ & 0.1 to 0.8 & $\mathrm{MPa}$ \\
\hline 3 & Design Temperature $(\mathrm{T})$ & 80 & ${ }^{\circ} \mathrm{C}$ \\
\hline 4 & Density of R22 Fluid ( $\rho f$ ) & 1330 & $\mathrm{~kg} \mathrm{~m}^{-3}$ \\
\hline 5 & Viscosity of R22 Fluid (vf) & 0.000263 & $\mathrm{Pas}$ \\
\hline 6 & Gravity $(\mathrm{g})$ & 9.81 & $\mathrm{~m} \mathrm{~s}^{-2}$ \\
\hline 7 & Turbine Chamber Diameter (D) & 0.134 & $\mathrm{~m}$ \\
\hline 8 & Turbine Chamber Height (h) & 0.045 & $\mathrm{~m}$ \\
\hline 9 & Inlet Nozzle Diameter (di) & 0.004 & $\mathrm{~m}$ \\
\hline 10 & Inlet Nozzle Length $(\mathrm{Li})$ & 0.038 & $\mathrm{~m}$ \\
\hline 11 & Outlet Nozzle Diameter (do) & 0.016 & $\mathrm{~m}$ \\
\hline 12 & Outlet Nozzle Length (Lo) & 0.016 & $\mathrm{~m}$ \\
\hline 13 & Turbine Blade Outer Diameter (D1) & 0.122 & $\mathrm{~m}$ \\
\hline 14 & Turbine Blade Inner Diameter (D2) & 0.057 & $\mathrm{~m}$ \\
\hline 15 & Turbine Blade Area (As) & 0.000672 & $\mathrm{~m}^{2}$ \\
\hline 16 & Turbine Blade Quantity (NST) & 18 & pes \\
\hline 17 & Turbine Runner Mass (mT) & 0.32 & $\mathrm{~kg}$ \\
\hline 18 & First Uphill Angle $(\alpha 1)$ & 12 & $\mathrm{O}^{\circ}$ \\
\hline 19 & Top Angle $(\alpha 2)$ & 30.9 & o \\
\hline 20 & Outlet Angle $(\alpha 3)$ & 47.1 & o \\
\hline 21 & Generator Efficiency ( $\eta \mathrm{g})$ & 82 & $\%$ \\
\hline
\end{tabular}

Table 2. Initial design parameter of turbine runner.

ORC (Organic Rankine Cycle) Turbine has two main components groups which become the most important part of turbine system performance optimization. Therefore, the initial turbine design parameters discussed will also be divided 
into two groups of parameters, that is (1) the initial design parameters in housing and housing cover and (2) the initial design parameters on the turbine runner. The initial design parameters can be seen in Table 1 and Table 2 .

\subsection{Turbine design calculation using mathematical modeling}

Calculations using this mathematical modeling will be divided into two groups, that is (i) Calculations on housing and housing cover design and (ii) Calculation on turbine runner design. The results of calculations are shown in Table 3 , Table 4, and Table 5. Graphs of inlet nozzle diameter vs turbine rotation and inlet nozzle diameter vs turbine torque at pressure of $0.8 \mathrm{MPa}$ presented in Figure 12. Graphs of inlet nozzle diameter vs power at pressure of $0.8 \mathrm{MPa}$ and turbine head vs volume flow Rate at constant turbine rotation of $4918 \mathrm{rpm}$ ( $1 \mathrm{rpm}=1 / 60 \mathrm{~Hz}$ ) shown in Figure 13.

Table 3. Calculation results of thickness on housing and housing cover.

\begin{tabular}{ccccccccc}
\hline Part Name & $\begin{array}{c}\mathbf{P} \\
(\mathbf{M P a})\end{array}$ & $\begin{array}{c}\mathbf{t}_{\mathbf{s}} \\
\mathbf{( m m )}\end{array}$ & $\begin{array}{c}\mathbf{t}_{\mathbf{s i}} \\
(\mathbf{m m})\end{array}$ & $\begin{array}{c}\mathbf{t}_{\mathbf{n}} \\
(\mathbf{m m})\end{array}$ & $\begin{array}{c}\mathbf{t}_{\mathbf{n i}} \\
(\mathbf{m m})\end{array}$ & $\begin{array}{c}\mathbf{t}_{\mathbf{m i n}} \\
(\mathbf{m m})\end{array}$ & $\begin{array}{c}\mathbf{t}_{\text {nom }} \\
(\mathbf{m m})\end{array}$ & $\begin{array}{c}\text { Design } \\
\text { Status }\end{array}$ \\
\hline Shell Housing & 0.8 & 0.25 & 1.25 & 0.00 & 0.00 & 1.25 & 4 & OK \\
Bottom Head Housing & 0.8 & 2.95 & 3.95 & 0.00 & 0.00 & 3.95 & 5 & OK \\
Housing Cover & 0.8 & 2.95 & 3.95 & 0.00 & 0.00 & 3.95 & 5 & OK \\
Inlet Nozzle & 0.8 & 0.25 & 1.25 & 0.011 & 1.01 & 1.13 & 10.5 & OK \\
Outlet Nozzle & 0.8 & 0.25 & 1.25 & 0.034 & 1.03 & 1.14 & 4.5 & OK \\
\hline
\end{tabular}

Table 4. Calculation results at constant pressure of $0.8 \mathrm{mpa}$.

\begin{tabular}{cccccccccc}
\hline $\begin{array}{c}\mathbf{P}_{\mathbf{i}} \\
(\mathbf{M P a})\end{array}$ & $\begin{array}{c}\mathbf{d}_{\mathbf{i}} \\
(\mathbf{m m})\end{array}$ & $\begin{array}{c}\mathbf{A}_{\mathbf{i}} \\
\left.\mathbf{( m}^{\mathbf{2}}\right)\end{array}$ & $\begin{array}{c}\mathbf{F}_{\mathbf{i}} \\
\mathbf{( N )}\end{array}$ & $\begin{array}{c}\boldsymbol{v}_{\boldsymbol{T}} \\
\left(\mathbf{m ~ s}^{-\mathbf{1}}\right)\end{array}$ & $\begin{array}{c}\mathbf{H} \\
(\mathbf{m})\end{array}$ & $\begin{array}{c}\mathbf{n} \\
(\mathbf{r p m})\end{array}$ & $\begin{array}{c}\mathbf{T} \\
\mathbf{( N ~ \mathbf { m } )}\end{array}$ & $\begin{array}{c}\mathbf{P}_{\mathbf{T}} \\
\mathbf{( k W )}\end{array}$ & $\begin{array}{c}\mathbf{P}_{\mathbf{L}} \\
(\mathbf{k W})\end{array}$ \\
\hline 0.8 & 4 & $1.26 \mathrm{e}-05$ & 10.05 & 31.4 & 61.3 & 4,918 & 0.61 & 0.3 & 0.3 \\
0.8 & 5 & $1.96 \mathrm{e}-05$ & 15.71 & 49.1 & 61.3 & 7,684 & 0.96 & 0.8 & 0.6 \\
0.8 & 6 & $2.83 \mathrm{e}-05$ & 22.62 & 70.7 & 61.3 & 11,066 & 1.38 & 1.6 & 1.3 \\
0.8 & 7 & $3.85 \mathrm{e}-05$ & 30.79 & 96.2 & 61.3 & 15,061 & 1.88 & 3.0 & 2.4 \\
0.8 & 8 & $5.03 \mathrm{e}-05$ & 40.21 & 125.7 & 61.3 & 19,672 & 2.45 & 5.1 & 4.1 \\
0.8 & 9 & $6.36 \mathrm{e}-05$ & 50.89 & 159.0 & 61.3 & 24,898 & 3.10 & 8.1 & 6.6 \\
0.8 & 10 & $7.85 \mathrm{e}-05$ & 62.83 & 196.3 & 61.3 & 30,738 & 3.83 & 12.3 & 10.1 \\
\hline
\end{tabular}

Table 5. Calculation results of head (h) and volume flow rate (q) at constant turbine rotation of $4918 \mathrm{rpm}$.

\begin{tabular}{ccccc}
\hline $\mathbf{n}$ & $\mathbf{d i}$ & $\mathbf{A i}$ & $\mathbf{Q}$ & $\mathbf{H}$ \\
$(\mathbf{r p m})$ & $(\mathbf{m m})$ & $\left.\mathbf{( m}^{\mathbf{2}}\right)$ & $\mathbf{( m )}$ & $\mathbf{( m )}$ \\
\hline 4,918 & 4.0 & $1.26 \mathrm{e}-05$ & 0.2 & 61.3 \\
4,918 & 5.0 & $1.96 \mathrm{e}-05$ & 0.3 & 39.2 \\
4,918 & 6.0 & $2.83 \mathrm{e}-05$ & 0.4 & 27.3 \\
4,918 & 7.0 & $3.85 \mathrm{e}-05$ & 0.6 & 20.0 \\
4,918 & 8.0 & $5.03 \mathrm{e}-05$ & 0.8 & 15.3 \\
4,918 & 9.0 & $6.36 \mathrm{e}-05$ & 1.0 & 12.1 \\
4,918 & 10.0 & $7.85 \mathrm{e}-05$ & 1.2 & 9.8 \\
4,918 & 11.0 & $9.5 \mathrm{e}-05$ & 1.5 & 8.1 \\
\hline
\end{tabular}


The graphs below are graphs of calculation results:

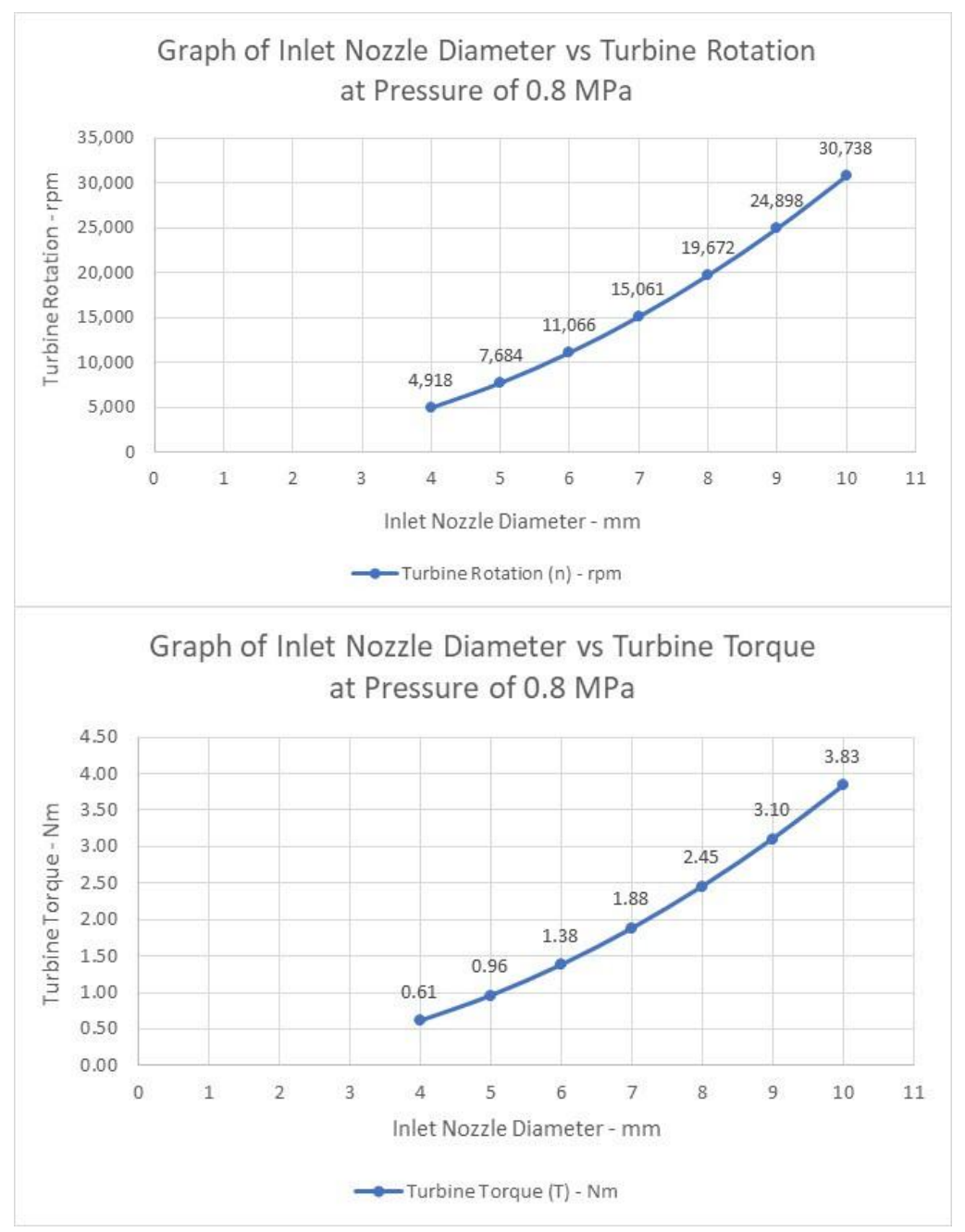

Fig. 12. Graphs of inlet nozzle diameter vs turbine rotation (top) and inlet nozzle diameter vs turbine torque at pressure of $0.8 \mathrm{MPa}$ (bottom). 

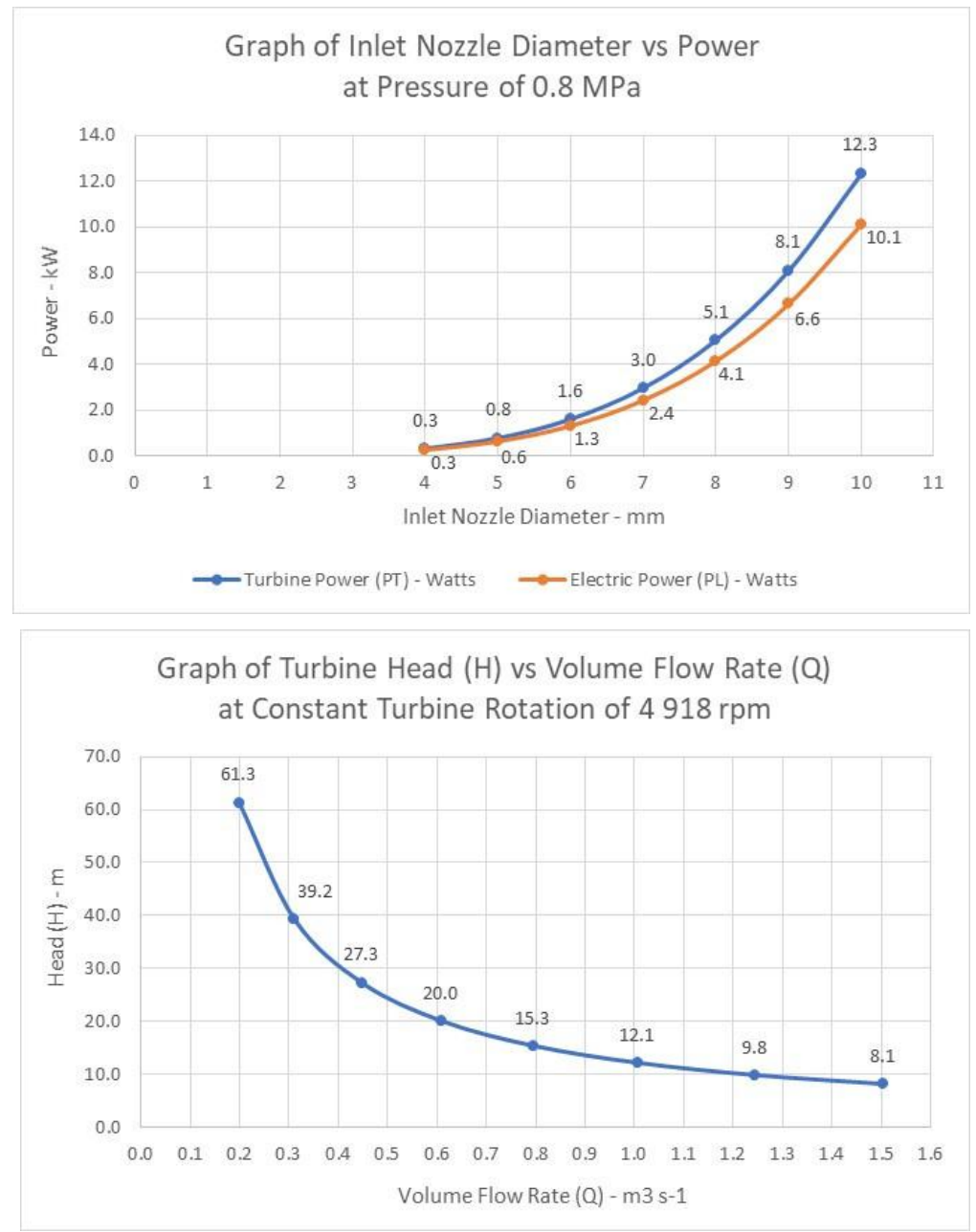

Fig. 13. Graphs of inlet nozzle diameter vs power at pressure of $0.8 \mathrm{MPa}$ (top) and turbine head vs volume flow rate at constant turbine rotation of $4918 \mathrm{rpm}$ (bottom).

\subsection{Turbine design and simulation using fea}

In the simulation of turbine design using FEA, simulation will be done testing the strength of materials from housing and housing cover components. The analysis report of the FEA simulation is shown in Figure 14: 

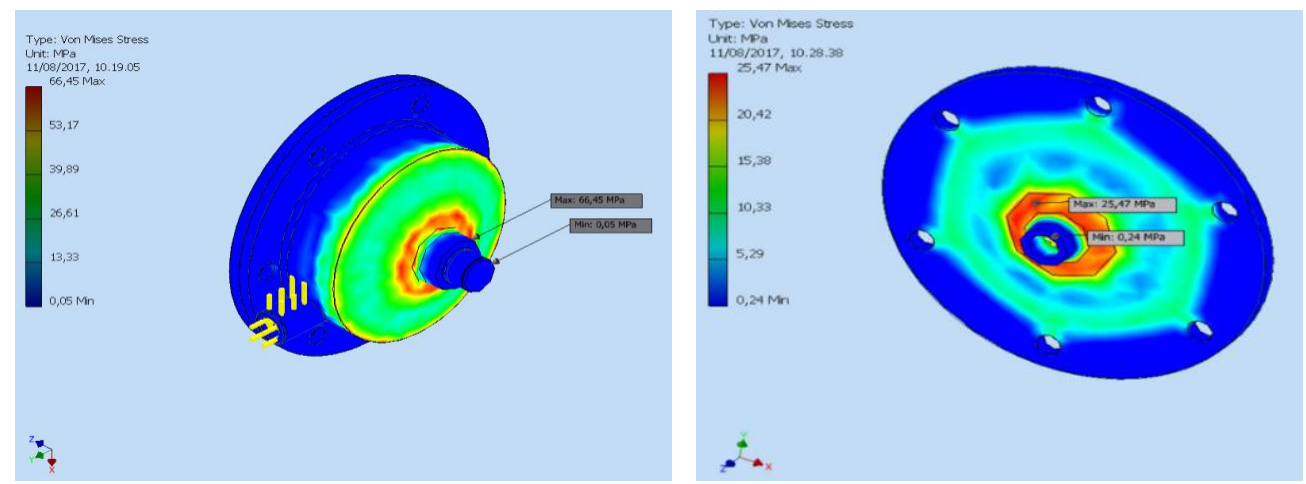

Fig. 14. Distribution of Von Mises Stress on housing (left) and housing cover (right).

From the FEA simulation result, the maximum Von Mises Stress that happened at housing was $66.45 \mathrm{MPa}$ and at housing cover was $25.47 \mathrm{MPa}$. This value is smaller than the yield strength value of the material, which is $215 \mathrm{MPa}$. Displacement and safety factor that occurred in housing and housing cover shown in Figure 15.
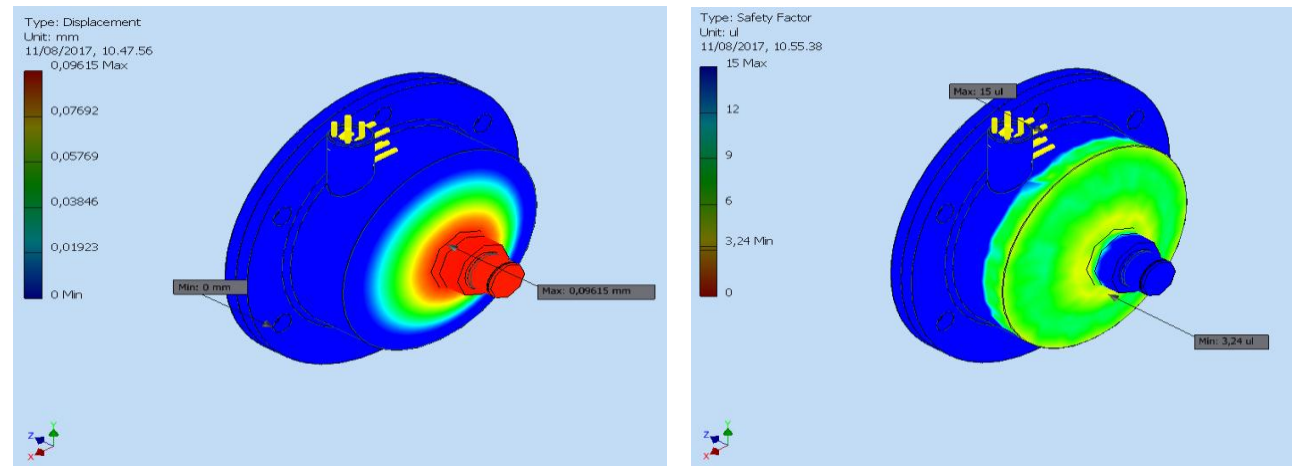

Fig. 15. Displacement (left) and safety factor (right) that occurred in housing and housing cover.

From the FEA simulation result, the maximum displacement that occurred in housing and housing cover is 0.09615 $\mathrm{mm}$. This value is less than $1 \mathrm{~mm}$. And the minimum Safety Factor that occurred in housing and housing cover was 3.24. Whereas according to the calculation rules of pressure vessel, the minimum permissible safety factor value of 3 .

\subsection{Turbine design simulation using CFD}

In the simulation of the turbine design using this CFD, simulation will be performed on the working fluid movement inside the turbine chamber and rotate the turbine runner. This simulation aims to find out some important design parameters, such as working fluid flow velocity at inlet and outlet nozzles, working fluid pressure, working fluid volume flow rate, turbine runner, turbine torque and generated power. Report analysis of the CFD simulation is presented in Figure 16 to Figure 19. 

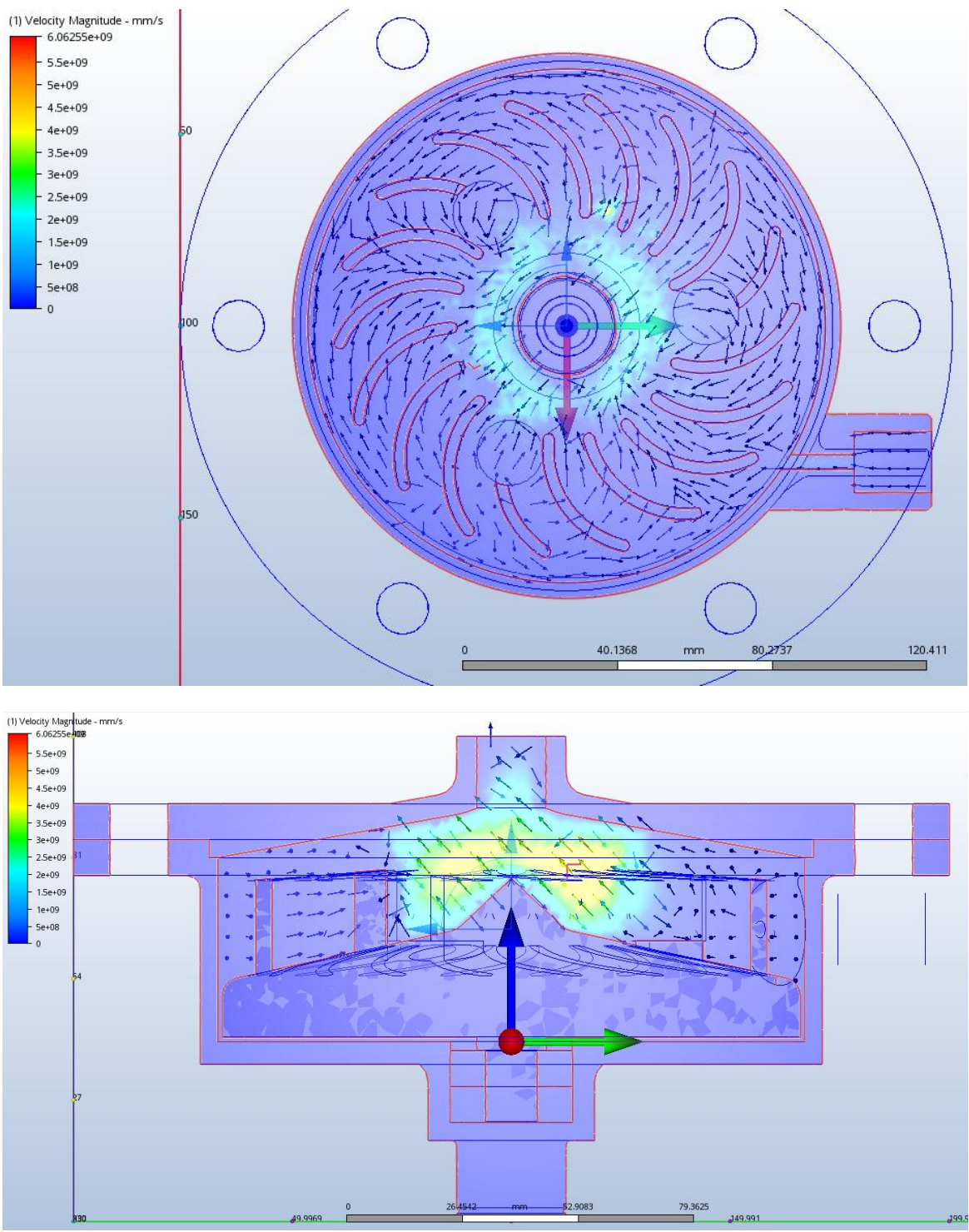

Fig. 16. CFD simulation results - Inlet (top) and outlet (bottom) working fluid velocity. 

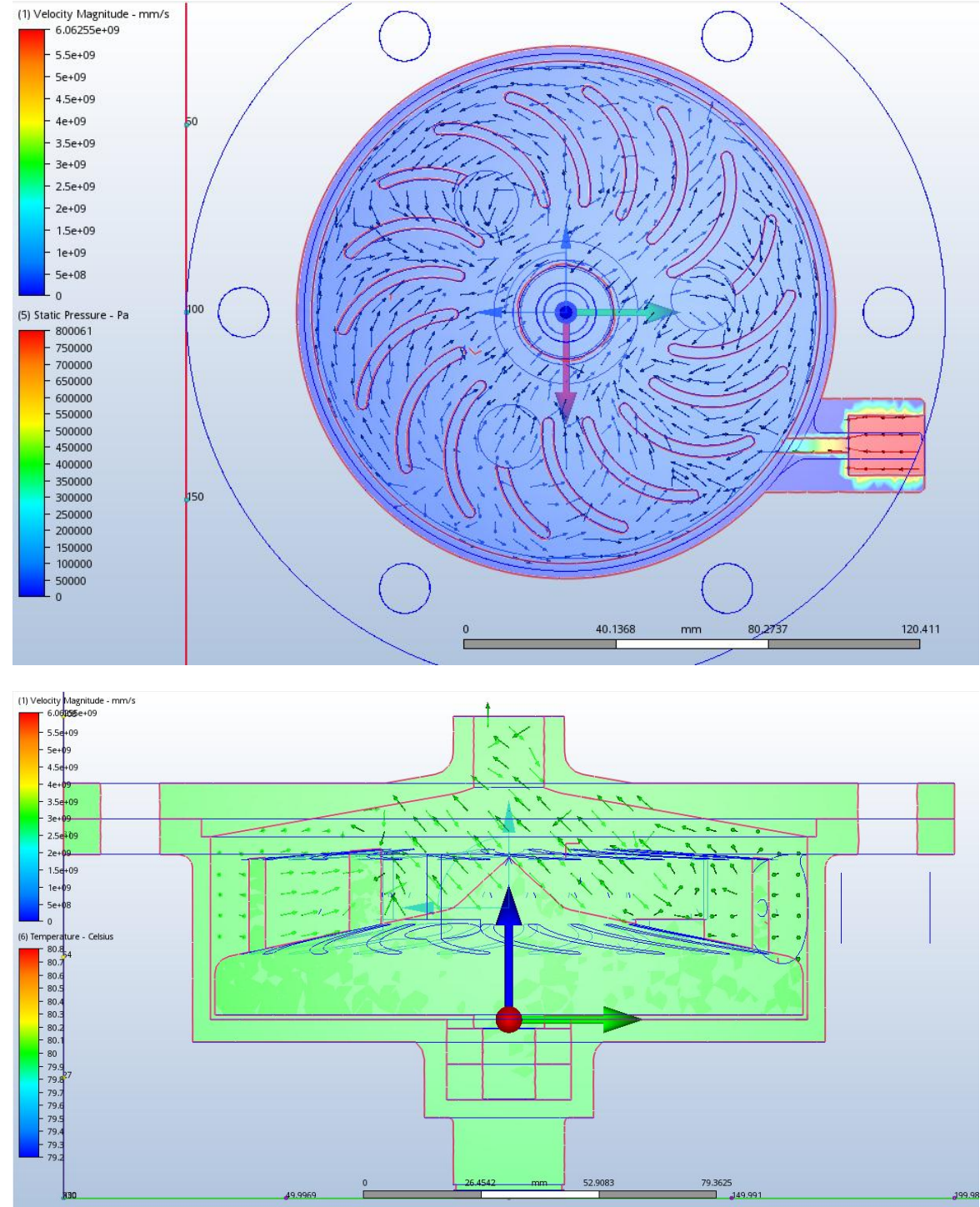

Fig. 18. CFD simulation results - Inlet (top) \& outlet (bottom) working fluid temperature. 
Motion Results

\begin{tabular}{|r|r|r|r|r|}
\hline 31 & Time (sec) & Linear Velocity $(\mathrm{mm} / \mathrm{s})$ & Angular Velocity (RPM) & Linear Displacement (1 ^ \\
\hline 32 & 31 & 0 & 3907.97 & \\
\hline 33 & 32 & 0 & 4257.7 & \\
\hline 34 & 33 & 0 & 4140.5 & \\
\hline 35 & 34 & 0 & 4980.82 & Close \\
\hline$<$ & & 0 & 5888.06 & \\
\hline
\end{tabular}

Fig. 19. CFD simulation results-Turbine runner rotation.

(i). Turbine power.

It can be seen the amount of Turbine Power as follows:

$$
P_{T}=T 2 \pi n / 60=(0.61) \times 2 \times(3.14) \times(5,888) / 60=376 \mathrm{~W}
$$

(ii). Electrical power.

Once turbine power is known, electrical power can be calculated using the Equations as follows:

$$
P_{L}=P_{T} \eta_{g}=376 \times 0.82=308.32 \mathrm{~W}
$$

So the amount of turbine power is $376 \mathrm{~W}$ and the amount of electrical power is $308.32 \mathrm{~W}$.

\section{Conclusion}

From the calculation using mathematical modeling, it can be seen that when the fluid pressure is constant at $0.8 \mathrm{MPa}$ and the inlet nozzle dimension varies, the magnitude of the turbine rotation speed, turbine rotation, turbine torque, turbine power and electrical power will be getting bigger as the inlet nozzle dimension. From the simulation result using FEA (Finite Element Analysis), it can be seen that housing and housing cover design for ORC turbine, safe and feasible to make. From the simulation results using CFD (Computational Fluid Dynamics), it can be seen that the turbine runner design for ORC turbine, at inlet working fluid pressure of $0.8 \mathrm{MPa}$ and $4 \mathrm{~mm}$ inlet nozzle dimension, produces a good working fluid flow distribution and turbine rotation, and is estimated to produce electrical power approximately $308.32 \mathrm{~W}$.

\section{References}

1. L. Aditya, T.M.I. Mahlia, B. Rismanchi, H.M. Ng, M.H. Hasan, H.S.C. Metselaar, et al. Renew. Sust. Energ. Rev., 73(2017):1352-1365 (2017). https://www.sciencedirect.com/science/article/pii/S1364032117302484

2. M. Amin, N. Putra, E.A. Kosasih, E. Prawiro, R.A. Luanto, T.M.I. Mahlia. Appl. Therm. Eng., 112(2017):273-280 (2017). https://www.sciencedirect.com/science/article/pii/S1359431116323845

3. T.M.I. Mahlia, J.Y. Lim, L. Aditya, T.M.I. Riayatsyah, A.E. Pg Abas, Nasruddin. Methodology for implementing power plant efficiency standards for power generation: potential emission reduction. Clean Tech n Environ Policy. Berlin: Springer (2017). pp. 1-19. https://link.springer.com/article/10.1007/s10098-017-1473-3

4. M. Hanif, T.M.I. Mahlia, H.B. Aditiya, M.S.A. Bakar. Biofuel Research Journal, 4(1):537-544 (2017). https://www.biofueljournal.com/article_43430.html

5. N. Hossain, J.H. Zaini, T.M.I. Mahlia. International Journal of Technology, 8(1):5-18 (2017). http://www.ijtech.eng.ui.ac.id/old/index.php/journal/article/view/3948

6. Nasruddin, M.I. Alhamid, Y. Daud, A. Surachman, A. Sugiyono, H.B. Aditya, et al. Renew. Sust. Energ. Rev., 53(2016):733-740 (2016). https://www.sciencedirect.com/science/article/pii/S1364032115010023

7. A.S. Silitonga, H.H. Masjuki, H.C. Ong, T. Yusaf, F. Kusumo, T.M.I. Mahlia. Industrial Crops and Products. 85(2016):274-286 (2016). https://www.cabdirect.org/cabdirect/abstract/20163129770 
8. T.M.I. Mahlia. Renewable Energy. 27(2):293-300 (2002).

https://www.sciencedirect.com/science/article/pii/S096014810100177X

9. T.M.I. Mahlia. Energy Conversion and Management. 44(5):723-730 (2003). https://www.sciencedirect.com/science/article/pii/S0196890402000857

10. T.M.I. Mahlia, M.Z. Abdulmuin, T.M.I. Alamsyah, D. Mukhlishien. Renewable Energy. 28(8):1235-1256 (2003). https://www.sciencedirect.com/science/article/pii/S0960148102002185

11. H.H. Masjuki, T.M.I. Mahlia, I.A. Choudhury, R. Saidur. Energy Conversion and Management. 43(6):763-770 (2002). https://www.sciencedirect.com/science/article/pii/S0196890401000747

12. P. Prasetyo. Studi penentuan geometri turbin radial aliran masuk pada siklus rankine organik dengan fluida kerja R134a. [Determination study of radial turbine inlet flow geometry in organic rankine cycle with R134a working fluid]. [Undergraduate Thesis]. Fakultas Teknik Mesin dan Dirgantara. Institut Teknologi Bandung (2015). [in Bahasa Indonesia]. https://slides.tips/studi-penentuan-geometri-turbin-radial-aliran-masuk-pada-siklus-rankineorganik.html\#

13. E. Bellos, C. Tzivanidis. Energy Convers. Manag. 156:427-439 (2018). https://www.sciencedirect.com/science/article/pii/S019689041731110X

14. O. Dumont, R. Dickes, M. De Rosa, R. Douglas, V. Lemort. Energy Convers. Manag. 157:294-306 (2018). https://www.sciencedirect.com/science/article/pii/S0196890417311731

15. A. Sadreddini, M. Fani, M. Ashjari Aghdam, A. Mohammadi. Energy Convers. Manag. 157:111-122 (2018). https://www.sciencedirect.com/science/article/pii/S019689041731107X

16. E. Saloux, M. Sorin, H. Nesreddine, A. Teyssedou. Appl. Therm. Eng. 129:628-635 (2018). https://www.sciencedirect.com/science/article/pii/S135943111734591X

17. D. Vera, F. Jurado, J. Carpio, S. Kamel. Energy. 144:41-53 (2018). https://www.sciencedirect.com/science/article/pii/S0360544217320108

18. M. Yari, L. Ariyanfar, E.A. Aghdam. Renewable Energy. 119:262-281 (2018). https://www.sciencedirect.com/science/article/pii/S096014811731217X

19. M. Arifin. Penentuan geometri rotor dan analisis parameter kinerja turbo-expander radial untuk sistem siklus rankine organik. [Determination of rotor geometry and performance parameters analysis of radial turbo-expander for organic rankine cycle system]. [Thesis]. Program Studi Teknik Mesin, Institut Teknologi Bandung (2014). [in Bahasa Indonesia].

https://www.researchgate.net/profile/Maulana_Arifin/publication/272623129_Determination_Rotor_Geometry_An d Analysis Performance Parameters Of Turbo-

Expander_Radial_For_Organic Rankine Cycle System/links/54f68d470cf21d8b8a5cc6d7/Determination-RotorGeometry-And-Analysis-Performance-Parameters-Of-Turbo-Expander-Radial-For-Organic-Rankine-CycleSystem.pdf

20. A.D. Yunus. Mesin konversi energi. [Machine of energy conversion]. Jakarta: Darma Persada University (2012). [in Bahasa Indonesia]. http://ft.unsada.ac.id/wp-content/uploads/2012/06/bab 1-2_mke.pdf

21. A.N. Firdaus. Variasi laju pendinginan cooling tower terhadap sistem ORC (organic rankine cycle) dengan fluida kerja $R-123$. [Cooling rate variation of cooling tower on ORC (organic rankine cycle) system with R-123 working fluid]. [thesis]. Fakultas Teknik Industri. Institut Teknologi Sepuluh Nopember (2014). [in Bahasa Indonesia]. http://docplayer.info/43753875-Studi-variasi-laju-pendinginan-cooling-tower-terhadap-sistem-orc-organic-rankinecycle-dengan-fluida-kerja-r-123.html

22. S. Quoilin, V. Lemort. The organic rankine cycle: Thermodynamics application and optimization. UNESCO: Encyclopedia of Life Support System (2014). pp. 1-12. https://www.eolss.net/sample-chapters/C05/E6-35-4300.pdf

23. L.D. Lio, G. Manente, A. Lazzaretto. Applied Energy. 205:187-209 (2017). https://www.sciencedirect.com/science/article/pii/S0306261917309959

24. L. Guillaume, A. Legros, A. Desideri, V. Lemort. Applied Energy. 186(3):408-422 (2017). https://www.sciencedirect.com/science/article/pii/S0306261916303233

25. Z. Han, W. Fan, R. Zhao. Energy Conversion and Management. 150:259-268 (2017). https://www.sciencedirect.com/science/article/pii/S0196890417307379

26. J. Song, C.W. Gu, X. Ren. Energy Convers. Manag. 123:308-316 (2016). https://www.sciencedirect.com/science/article/pii/S019689041630512X

27. Z. Wang, L. Yin. Dongli Gongcheng Xuebao/Journal of Chinese Society of Power Engineering. 37(5):367-372 (2017).

https://www.researchgate.net/publication/320144727_Effects_of_Impeller_Twisting_Law_on_Performance_of the ORC_Radial_Inflow_Turbine

28. Z. Wang, L. Yin, Y. Liu, Q. Jiao, H. Qu. Dongli Gongcheng Xuebao/Journal of Chinese Society of Power Engineering. 37(10):801-807 (2017).

https://www.researchgate.net/publication/321888652_Analysis_on_Structure_and_Loss_of_Secondary_Flow_in_S tator_Cascades_of an_ORC_Radial_Inflow_Turbine 